\title{
EINSTEIN AND NAZI PHYSICS When science meets ideology and prejudice
}

\section{PHILIP BALL}

In the 1920s and 30s, in a Germany with widespread and growing anti-Semitism, and later with the rise of Nazism, Albert Einstein's physics faced hostility and was attacked on racial grounds. That assault was orchestrated by two Nobel laureates in physics, who asserted that stereotypical racial features are exhibited in scientific thinking. Their actions show how ideology can infect and inflect science. Reviewing this episode in the current context remains an instructive and cautionary tale.

Keywords: Albert Einstein, Nazism, anti-Semitism, science and ideology.

It was German society, Einstein said, that revealed to him his Jewishness. «This discovery was brought home to me by non-Jews rather than Jews», he wrote in 1929 (cited in Folsing, 1998, p. 488).

Shortly after the boycott of Jewish businesses at the start of April 1933, the German Students Association, emboldened by Hitler's rise to total power, declared that literature should be cleansed of the «un-German spirit». The result, on 10 May, was a ritualistic burning of tens of thousands of books «marred» by Jewish intellectualism. These included works by Sigmund Freud, Bertolt Brecht, Karl Marx, Stefan Zweig, Walter Benjamin - and Albert Einstein.

How could a scientific theory be subjected to pseudo-moralistic judgement based on race? Is it not simply either right or wrong? Most of the book-burners doubtless had not given those questions a moment's thought. That Einstein was a prominent Jew was enough to make his books fit for the bonfire.

But Einstein's science was attacked on racial grounds. That assault was orchestrated by two Nobel laureates in physics, who asserted that stereotypical racial features are exhibited in scientific thinking. Their actions show how ideology can infect and inflect science - and that this can happen at all levels of science's hierarchy of status and expertise. In an age when personal, professional, and political biases have been seen to influence the conduct and presentation of science in areas ranging from epidemiology and research into disease (the connection of smoking to cancer, and of HIV to AIDS) to climate change, this idea perhaps should come as no surprise. But it is for that very reason that the hostility Einstein's physics sometimes encountered in Germany in the 1920s and 30s remains an instructive and cautionary tale.

\section{AGAINST RELATIVITY}

Einstein's high-ranking antagonists within German physics were Philipp Lenard and Johannes Stark. Lenard was awarded the 1905 Nobel prize for his studies of cathode rays, the «radiation» emitted from hot metals. Lenard at first believed these rays to be fluctuations in the ether-like light, as it was then conceptualized. But in 1897 J. J. Thomson, director of the Cavendish Laboratory in Cambridge, showed that cathode rays have negative electric charge, being deflected

by electric and magnetic fields, and he concluded that they were in fact streams of particles, which became known as electrons.

Lenard also investigated the photoelectric effect: the expulsion of electrons from metals irradiated with ultraviolet light. He discovered that the energy of these electrons did not depend on the intensity of the light but only on its wavelength. When Einstein explained this result in 1905 in terms of Max 


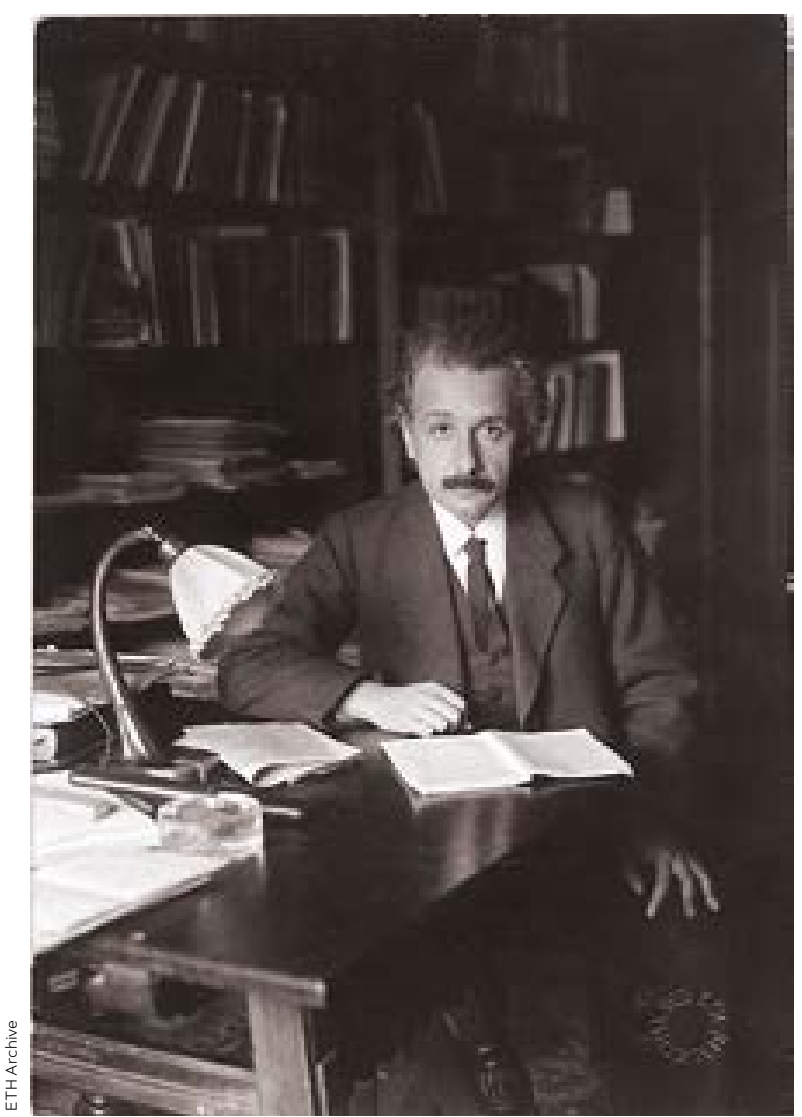

Albert Einstein in his office at the University of Berlin in 1920. In the following year he was awarded the Nobel Prize in Physics for his work on the photoelectric effect, the same field that another German physicist, Philipp Lenard, was researching. Lenard was one of Einstein's harshest critics, and his attacks would eventually incorporate racial elements.

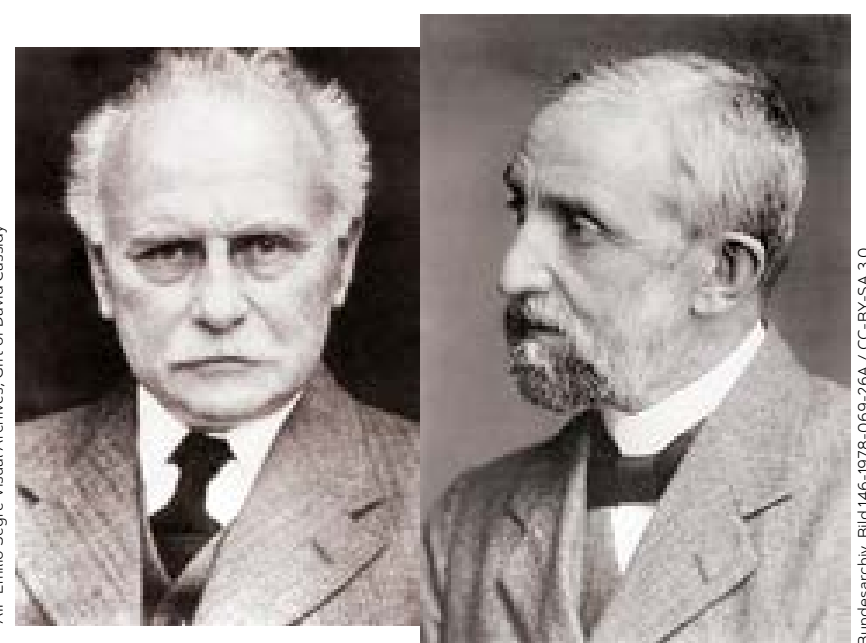

Johannes Stark (left) and Philipp Lenard (right) orchestrated attacks on Albert Einstein from within the scientific community. Both were Nobel laureates in physics, and they asserted that stereotypical racial features were exhibited in scientific thinking.

Lenard yearned for the spirit of German Romanticism, lamenting the encroachment of technology in modern life: an expression, he said, of the kind of materialism that infected both Communism and the Jewish spirit, the twin enemies of German greatness. He spoke of «the all-corrupting foreign spirit permeating physics and mathematics» - foreign here implying Jewish.

In 1919 the Nobel prize for physics was awarded to Johannes Stark for his discovery of the effect of electric fields on the energies of photons emitted from atoms as electrons jump between orbits. Like Lenard, Stark was an experimentalist befuddled by the mathematical complexity that had recently entered physics. He was another extreme nationalist whose right-wing views were hardened by the First World War. He too felt that Einstein had stolen his ideas, and when he found himself being passed over for academic appointments, he attributed it to the self-interest of a «Jewish and pro-Semitic circle».

As anti-Semitism increased, Einstein began to be subjected to racially motivated criticism and abuse in the German popular and academic press. He was denounced at a public meeting held in Berlin in 1920 organized by the Working Group of German Scientists for the Preservation of Pure Science, a more or less fictitious body concocted by the farright activist Paul Weyland. The meeting itself took 
fearing that he might be physically endangered. This wasn't paranoia; in June the Jewish Foreign Minister of the Weimar government Walther Rathenau, who Einstein knew well, was assassinated in Berlin by two ultra-nationalist army officers. Lenard had refused to lower the flag of his institute at Heidelberg as a mark of respect for the murdered minister; when he was reprimanded by the university, he announced his resignation in disgust.

When, in 1923, the National Socialists staged the unsuccessful Munich putsch against the Weimar government, Lenard and Stark recognized a kindred spirit in their leader. In May 1924 they wrote an article called «The Hitler spirit and science». Hitler and his comrades, they said,

... appear to us as God's gifts from times of old when races were purer, people were greater, and minds were less deluded... He is here. He has revealed himself as the Führer of the sincere. We shall follow him. (Hentschel, 1996, p. 9)

The Nazi leader noted this pledge of support, and he and Rudolf Hess visited Lenard in 1926.

For Stark and Lenard, the problem at the core of German physics was not merely the nepotism of the Jews and their supporters, nor the obscure theories and unpatriotic internationalism of Einstein. The fundamental problem lay with a foreign and degenerate approach to science itself. The popular notion that science has a universal nature and spirit, they said, is quite wrong. In an article called «National Socialism and science», Stark wrote in 1934 that science, like any other creative activity, «is conditioned by the spiritual and characterological endowments of its practitioners» (Mosse, 1966, p. 206): Jews did science differently from true Germans. What Germany needed, Lenard and Stark declared, was a truly German, «Aryan» physics (Deutsche Physik) that rejected the over-mathematical, abstract fabrications of relativistic physics in favour of a rigorously experimental approach.

Some others of like mind embraced the idea. According to the Nazi mathematician Bruno Thüring, Einstein's theory of relativity,
Albert Einstein was in the United States when Hitler came to power in 1933, and vowed not to return. The photograph shows the physicist receiving his certificate of American citizenship from Judge Phillip Forman on 1 October 1940.

... is not the keystone of a development, but a declaration of total war, waged with the purpose of destroying what lies at the basis of this development, namely, the world view of German man... Thus, in its consequences the theory of relativity appears to be less a scientific than a political problem. (Mosse, 1966, p. 213)

The anti-Einstein activism of Stark, Lenard, and their fellow travellers continued through the early 1930s. In 1931 a hundred German intellectuals contributed to a volume denouncing Einstein and his theories. However useful this small booklet might be today to maverick thinkers (including, recently, a British government minister) intent on implying how wrong «experts» can be, the fact is that among the signatories there were almost no German physicists of any note. From his peers Einstein generally received support for his scientific ideas -if, however, sometimes carefully kept distinct from the «problematic» aspects of Einstein's politics and «race». 
mathematicians], we shall rise like one man to protest against it.» The next day, the newspapers reported that the same scientists and many others had been dismissed owing to their Jewish race and their disgraceful influence on universities and students. And all the other members of Göttingen University remained sitting and had forgotten their intention to rise and protest. (Rosbaud, 1945)

The sense of helpless fatalism here seems not so much misjudged as calculatedly self-serving. The Hungarian physicist Leo Szilard, working at the University of Berlin in 1933 but shortly to leave for England, expressed the situation very well:

I noticed that the Germans always took a utilitarian point of view. They asked, «Well, suppose I would oppose this, what good would I do? I wouldn't do very much good, I would just lose my influence. Then why should I oppose it?» You see, the moral point of view was completely absent, or very weak, and every consideration was simply, what would be the predictable consequence of my action. And on that basis did I reach the conclusion in 1931 that Hitler would get into power, not because the force of the Nazi revolution were so strong, but rather because I thought that there would be no resistance whatsoever. (Szilard, 1979)

\section{EINSTEIN EXPUNGED}

When Hitler came to power,

Einstein was visiting the

California Institute of Technology. On 10 March he announced that he would not return to live in his native country, choosing instead «a country where civil liberty, tolerance, and equality before the law prevail» (Clark, 1973, p. 431).

The nationalistic Prussian Academy of Sciences was outraged. As its president, Max Planck was expected to condemn his friend. He did so, arguing that Einstein's comments and actions were not helping the situation. But Einstein would not back down. «I do not share your view», he wrote to his colleague Max von Laue, «that the scientist should observe silence in political matters, i.e., human affairs in the broader sense... Does not such restraint signify a lack of responsibility?» (Cassidy, 2009, pp. 207-208).

The presiding secretary of the Prussian Academy of Sciences, meteorologist Heinrich von Ficker, urged Planck to demand Einstein's resignation. Einstein was ahead of him, tendering his resignation before Planck's letter arrived. Worried about how this looked to the German authorities, another of the Academy's secretaries, the orientalist Ernst Heymann, drafted a statement accusing Einstein of «participation in atrocity-mongering in France and America» (Einstein, 1949, p. 82). In the minutes of the Academy's meetings, Planck sheepishly noted the unquestioned and abiding importance of Einstein's scientific work, before writing that it was «deeply to be regretted that Einstein has by his own political behaviour made his continuation in the Academy impossible» (Heilbron, 2000, p. 159).

Einstein then issued a public statement rejecting assertions of «atrocity-mongering» and saying that he «did not wish to live in a country where the individual does not enjoy equality before the law, and freedom of speech and teaching» (Einstein, 1954 , p. 206). To accept the situation in Germany, Einstein subsequently told the Academy's officials, «would have been equivalent to a repudiation of all those notions of justice and liberty for which I have stood all my life» (Einstein, 1949, p. 86).

Planck's view that nothing could be done to resist the demands of the Nazis, and the attitude of the other officials of the Academy that nothing needed to be done, were in the end indistinguishable in their consequences. «When faced with a choice between endangering their academy or acquiescing in the racist purge of the Prussian

Academy of Sciences», writes Walker, «the academy scientists surrendered their independence and became accomplices by helping the National Socialist state force the Jewish scientists out of the academy» (Walker, 1995, pp. 92-93).

\section{THE WRONG BATTLE?}

Einstein's persecution as a Jew in Germany convinced him that assimilation was not the answer. Rather, he became associated with Zionism, campaigning and fund-raising for the formation of a Hebrew University in Jerusalem. But he was too much of an internationalist to embrace Jewish nationalism, and doubted the need for a separate Jewish state in Palestine; famously he turned down the offer of becoming Israel's president after the death of the first, his friend the biochemist Chaim Weizmann, in 1952. While declining on the grounds that he lacked «both the natural aptitude and the experience», he added in his letter to the Israeli government that 


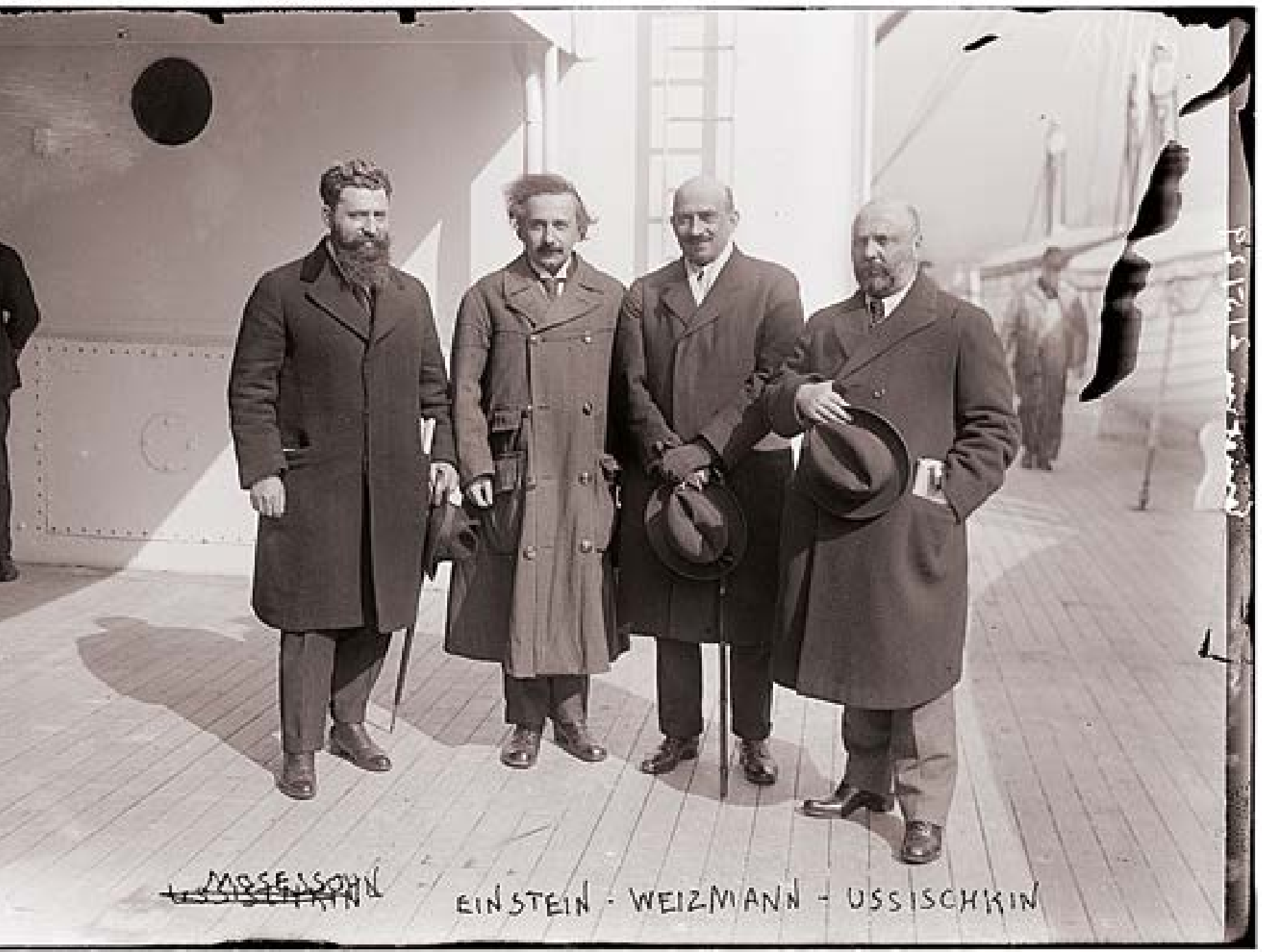

The persecution Einstein suffered in Germany as a Jew pushed him towards Zionism, although he was too much of an internationalist to embrace Jewish nationalism and doubted the need for a separate Jewish state in Palestine. This photograph, taken some time between 1915 and 1920, shows Einstein with Zionist leaders. From left to right, Ben-Zion Mossinson, Albert Einstein, Chaim Weizmann, and Menachem Ussishkin.

\section{«Einstein himself received at best rather timid support even from colleagues and friends who had no doubt that his science was correct»}

«my relationship to the Jewish people has become my strongest human bond, ever since I became fully aware of our precarious situation among the nations of the world» (cited in Nathan \& Norden, 1963, p. 572). By that stage the Holocaust had made this precariousness dreadfully evident. But it was his experience with the Deutsche Physiker in 1920s Germany that first stirred Einstein's awareness.

The battle fought within German physics in the 1930s was not that of apolitical scientists against the National Socialists, but of Einstein's supporters against the small but fanatical and influential group of «Aryan» physicists. One might have expected the National Socialists to embrace a physics that discredited Jews, but they were not so foolish. Physics under the Nazis was never really hijacked by ideology, for the political leaders were primarily interested in 
practical outcomes and not academic disputes. An internal memo in the Reich Education Ministry (which oversaw the universities) on the controversy over «Jewish physics» advises that «In the case of a purely scientific dispute, in my opinion, the Minister should keep himself out of it» (Hentschel, 1996, p. 141). Until nuclear fission was discovered in Berlin in 1938, physics was of little interest to the authorities, as it seemed to be largely irrelevant to the war preparations. And once atomic power looked possible, the Aryan physicists' advocacy of practical experiment over abstract theory did them no good because it could not deliver results. Rather, it was evidently that it was the proponents of «Jewish» quantum theory and relativity who truly understood the secrets of the atomic nucleus, and even the Nazis could see that they were the only ones likely to put the discoveries to good use.

Deutsche Physik floundered through the political ineptitude of Stark and Lenard. Stark in particular was apt more to antagonize than to persuade the Party officials. «Had he been less crazy», Heilbron (2000, p. 171) comments, «he would have been much more dangerous». This does not simply mean that the Aryan physicists undermined themselves; it shows that to wield power in Nazi Germany one needed to do more than regurgitate approved doctrines, prejudices, and formulas. One had to manipulate the competing power blocs, to exploit the right contacts, and forge useful allegiances. Stark could not play that game: he had no more judgement in politics than he did in science.

As a result, the attempt of Deutsche Physik to take over the academic system ultimately failed. But its opponents had to tread a fine line, so that their defence of Einstein's theories did not risk endorsing his unpopular political views. So long as they agreed to avoid too explicit an acknowledgement of the architect of the theory of relativity when they made use of it, they could generally get their way. During the war, Werner Heisenberg regularly omitted Einstein's name from his «cultural» lectures in occupied territories.

The struggle against Deutsche Physik, however frustrating for the German physicists who rejected it, offered a useful narrative after the war by supplying a criterion for partitioning physicists into those who were nazified and those who resisted them. In this

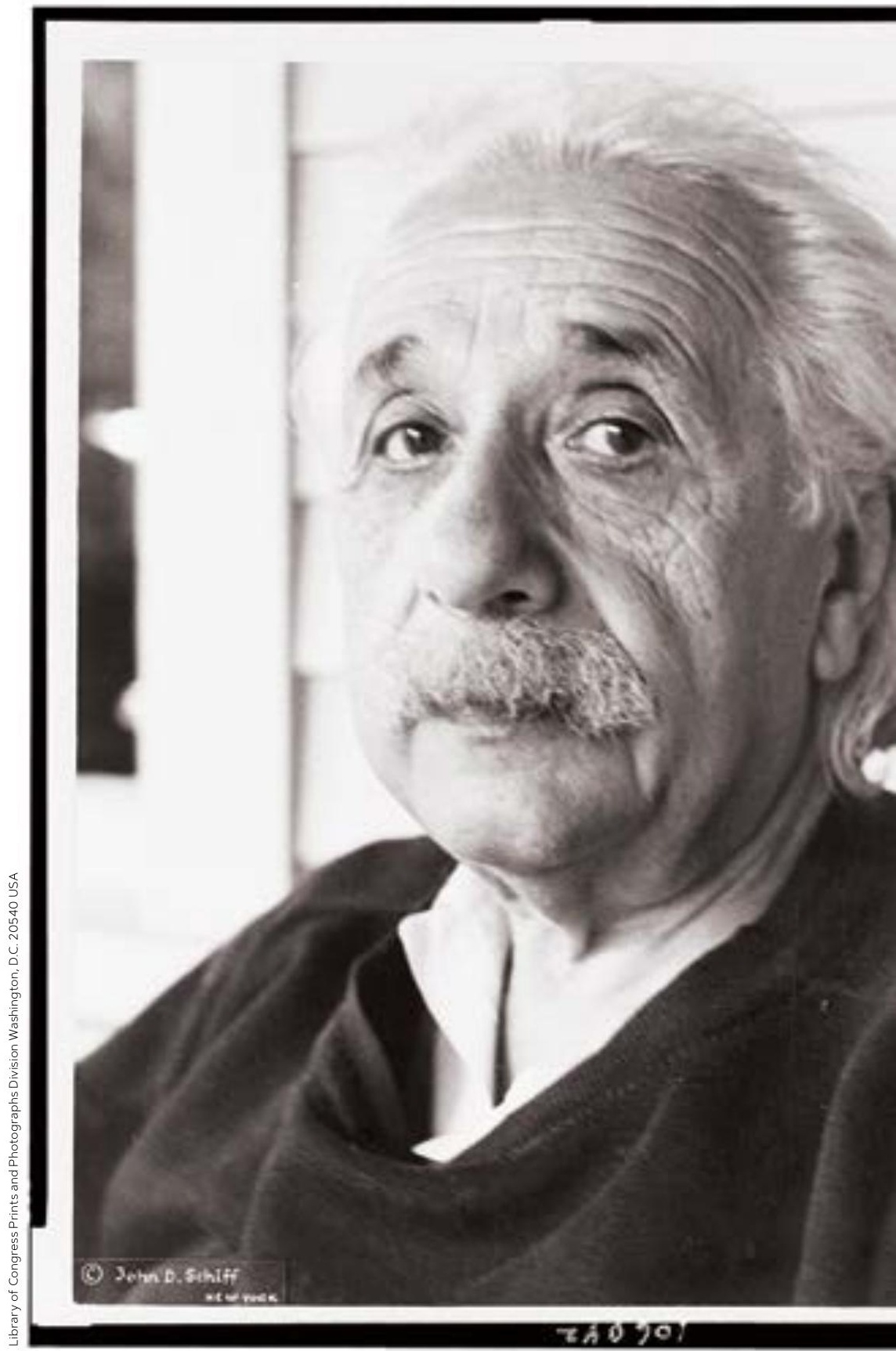


view, if you had opposed Aryan physics, you had in effect opposed the Nazis. All the guilt of the National Socialist era could then be transferred onto Lenard, Stark, and their supporters. It was partly for this reason that no physicist - not even Lenard or Stark - suffered any truly adverse consequences for their support of a murderous and racist regime.

\section{CONCLUSION}

The fact that Einstein's scientific work was in the end upheld and vindicated in the face of the antiSemitic attacks by the Nazis and their supporters is sometimes presented today as evidence that scientific truth is stronger than political ideology, and will prevail.

We might hope that this is so, but such optimism receives little support from the case of physics in Nazi Germany. Einstein himself received at best rather timid support even from colleagues and friends who had no doubt that his science was correct (which was the position of the majority of German physicists). Even many of those advocates were careful to draw distinctions between their support for the science and opposition in principle to the prejudice he faced.

And while it is tempting to regard the prevalence of Einstein's ideas, in relativistic physics in particular, as a heroic triumph of true science over ideology, that does not reflect the reality. The Nazi authorities had nothing invested in the success or failure of Einstein's physics; they were rather indifferent to the academic arguments with the «Aryan physicists».

In contrast to the case of anti-Darwinian Lysenkoism under Stalin, there was nothing in relativistic physics that obviously conflicted with Nazi ideology, and therefore no reason for it per se to trouble the regime. All that mattered to the Nazi leaders was that Einstein should not, as a prominent Jew, be celebrated for his intellectual achievements: the threat, such as it was, came from Einstein as an individual, not Einsteinian physics.

At any rate, while the dispute about Aryan physics continued through the late 1930s, the Nazis tightened their grip on German science regardless. The chemists mostly fell into line; in anthropology and medicine, the collusion of some researchers had horrific consequences. Physics was another matter: just docile enough for its lapses, evasions, and occasional defiance to be tolerated. In the final analysis, the reluctant physicists were obliging and dutiful enough.

What was lacking was any sustained opposition to political interference at the institutional level. The matter was merely a question of individual conscience, and if German scientists were to oppose Nazi anti-Semitism, they could expect little professional support from their colleagues. Today that situation is changing. But as political repression returns to nations that might have been thought to have achieved a robust democratic openness, it becomes ever more urgent to heed the lessons of what happened when Einstein's science collided with state ideology. ()

«lt becomes ever more urgent
to heed the lessons of what
happened when Einstein's
science collided with state
ideology»

REFERENCES

Cassidy, D. C. (2009). Beyond uncertainty: Heisenberg, quantum physics, and the bomb. New York: Bellevue Literary Press.

Clark, R. W. (1973). Einstein: The life and times. London: Hodder \& Stoughton.

Einstein, A. (1949). The world as I see it. New York: Philosophical Library.

Einstein, A. (1954). Ideas and opinions. New York: Bonanza Books.

Folsing, A. (1998). Albert Einstein: A biography. Harmondsworth: Penguin.

Heilbron, J. L. (2000). The dilemmas of an upright man: Max Planck and the fortunes of German science. 2nd ed. Cambridge: Harvard University Press.

Hentschel, K. (Ed.). (1996). Physics and National Socialism: An anthology of primary sources. A. M. Hentschel (Transl.). Basel: Birkhauser Verlag.

Kershaw, I. (2008). Hitler, the Germans, and the final solution. New Haven: Yale University Press.

Kurlander, E. (2009). Living with Hitler. New Haven: Yale University Press. Mosse, G. L. (Ed.). (1966). Nazi culture: Intellectual, cultural and social life in the Third Reich. New York: Grosset \& Dunlap.

Nathan, O., \& Norden, H. (Eds.). (1963). Einstein on peace. New York: Simon \& Schuster.

Rosbaud, P. (1945). Rosbaud correspondence and manuscripts 1945. (Series IV, Box 28, Folder 42). Samuel Goudsmit Papers. American Institute of Physics.

Szilard, L. (1979, March). Excerpts. Leo Szilard: His versions of the facts II. Bulletin of the Atomic Scientists, 35(3), 55-59.

Van Dongen, J. (2007). Reactionaries and Einstein's fame: "German Scientists for the Preservation of Pure Science", relativity, and the Bad Nauheim Meeting. Physics in Perspective, 9(2), 212-230. doi: 10.1007/s00016-006-0318-y

Walker, M. (1995). Nazi science: Myth, truth and the German atomic bomb. New York: Plenum.

PHILIP BALL. Science writer and author (London, UK). He previously worked as an editor at Nature, and his many books on science and its interactions with the broader culture include Serving the Reich: The struggle for the soul of physics under Hitler (2014). His last book is Beyond weird: Why everything you thought you knew about quantum physics is different (2018). $₫$ p.ball@btinternet.com 